\title{
"Amongst Affectionate Female Friends"
}

\author{
Same-Sex Intimacy in Nineteenth-Century \\ Polish Correspondence
}

\begin{abstract}
Translation and introduction by Natalie Cornett
Translation of a letter from Narcyza Żmichowska to Wanda Grabowska, 26 January 1864. Published in Tadeusz Boy-Żeleński, ed., Narcyssa i Wanda: Listy Narcyzy Żmichowskiej do Wandy Grabowskiej (Żeleńskiej) (Narcyssa and Wanda: Letters from Narcyza Żmichowska to Wanda Grabowska [Żeleńska]) (Warsaw: Dom Książki Polskiej Spółka Akcyjna, 1930), pp. 32-34.
\end{abstract}

\section{Introduction}

The period between Poland's two great uprisings (1830-1831 and 1863) was marked by imperial repression of Polish cultural and political life, especially in the Russian and Prussian partitions. Yet it was also a period in which Polish intellectual circles both inside and outside Poland flourished, albeit clandestinely. Narcyza Żmichowska led a group of female writers, thinkers, and activists known as Entuzjastki (Enthusiasts), who were united by their commitment to live as independent women in an age of emerging nationalism that put the nation above all else, including class and gender. Żmichowska and her Enthusiasts wrote incessantly to each other, and some 1,200 or so of their letters have been published thus far while even more are kept in public and private archives. While the Enthusiasts were a small segment of Polish society, they made a disproportionately large contribution to public discourse on what it meant to be Polish, but especially female and independent. This concept of an independent Polish woman had no firm moorings in existing law, norms, and constructions. The Enthusiasts challenged prevailing notions of women's educational and intellectual potential not only by exploiting new patriotic networks and movements but also by creating new avenues for public action and involvement centered on deep affective relationships between women. 
Since the late nineteenth century, literary historians, public critics, and scholars have tried to identify the Enthusiasts and analyze their emerging and evolving ideology. ${ }^{1}$ However, the group itself has proved elusive; its diverse adherents had no formal organization and membership, or even a dogma or goal. ${ }^{2}$ They were of varying socioeconomic backgrounds, including landowning gentry (Paulina Zbyszewska), petty bourgeoisie (Narcyza Żmichowska), and impoverished professional (Emilia Gosselin). However, they could all be considered part of the Polish intelligentsia, the educated social stratum that emerged at the end of the eighteenth century and grew under the partitions. ${ }^{3}$ The intelligentsia was comprised of mostly former nobility whose titles were progressively stripped away by all three imperial powers but most ruthlessly under the Russian crown. Within the intelligentsia, one's cultural and educational capital mattered more than heritage or financial wealth. This made class boundaries more fluid and permeable than traditional gentry circles. ${ }^{4}$ From this group of educated intellectuals emerged the most fervent calls for revolutionary change, not only in terms of national emancipation from imperial regimes, but for social change as well. The concepts of national democracy, independence, and liberation of the peasantry combined with a language of messianic universalism of the Polish cause linked not only to religious motifs, but also to the larger struggles of European minority states against imperial regimes. The Enthusiasts, as a subgroup of women within this new class, envisioned and advocated for a resurrected Poland that included women as equally worthy national actors.

According to some literary scholars, the Enthusiasts first emerged with the publication of Poland's first women's journal, Pierwiosnek (Primrose), in $1838 .{ }^{5}$ But, if one emphasizes the political activities of the group in Polish pro-independence groups, its inception occurred only in the 1840s, centering on the Warsovian literary-political salon of Hipolit Skimborowicz and the editors of Przeglad naukowy (The scientific review), a popular political journal that argued for democratic change, Polish sovereignty, and women's emancipation. ${ }^{6}$ The editors and contributors of this journal, including Żmichowska and her female compatriots, were involved to varying degrees in pro-Polish activities focused on spreading the ideals of brotherly and sisterly national solidarity, especially among artisans and professionals in Warsaw. ${ }^{7}$ We know from letters and other records that Żmichowska's circle frequently aided families that suffered from the Russian crackdown on partisans and revolutionaries. ${ }^{8} \dot{Z}$ michowska and her friends also ran schools for girls in Warsaw and the surrounding countryside. ${ }^{9}$ They brought in textbooks and materials from the Prussian partition area that were banned in the Russian Congress Kingdom of Poland. Eventually, Russian authorities arrested the group centered around Przeglad naukowy for their insurrectionary activities that occurred in the midst of the violent protests and national uprisings that comprised the "Springtime of Nations" in 1848, of which Poland played a small and rather insignificant role compared to the larger and more successful uprisings in the nearby German and Hungarian lands. Żmichowska and her three friends received the worst sentences of all the women convicted of anti-Russian activities in $1851 .{ }^{10}$ The Russian Investigative Commission grouped the four separately from other convicted women in their records, and the authorities punished their treacherous acts of spreading "scandalous" propaganda, as well as their stubbornness in refusing to 
confess, by condemning them to exile and intensive surveillance after they served time in jail. ${ }^{11}$

The Enthusiasts relied on each other for emotional, intellectual and material support in the face of such hostile conditions. Their attempts to bring the woman question into the national debate were largely ignored or rejected. Meanwhile, their struggle for Polish independence was punished by the authorities and met with skepticism among patriotic circles. This antagonistic environment hindered the efficacy of their movement but also reinforced their bond as women who challenged gender inequality. In a male-dominated public sphere, they carved a space for women that served as the basis for their affective relationships. The political and the personal combined and interacted with the dynamics of the group and their relationships. These shifting emotional contours and intimacies of the Enthusiasts have been preserved through their robust letter-writing legacy.

\section{Epistolary Legacy in Historical Context}

Nineteenth-century Europe saw rising literacy rates for both men and women. This expanded literacy facilitated an outburst of literary productivity that in turn created a new world of popular opinion and debate. In Polish-speaking regions, this process of building a public sphere based on publicly consumed and available publications was complicated due to the formal partition of Poland into three separate entities under the jurisdiction of three separate empires. Each empire ruled its respective partition differently with regard to censorship of publications and regulation of printed material. Postal services and person-to-person exchanges of literary material existed among the partitions and beyond, and were key to providing those within Poland access to much-desired news, ideas, and publications from abroad. Of course, the threat of censorship or interception of letters by any of the imperial powers went alongside these exchanges, but many took the risk and developed means by which the authorities could not decipher their messages. Increasingly, women engaged in this form of communication, and before long created networks of "sisters" among whom they could confide in, relate to, and create common bonds of action and resistance.

The Enthusiasts were avid letter writers, and many tomes of their letters have been published since the end of the nineteenth century. The main volumes of Żmichowska's letters to fellow Enthusiasts and her family appeared in print already at the end of the nineteenth century, but were subject to state censorship before 1905 (when those controls largely expired). This meant that the letters were redacted in many cases to reflect not only political repression but also the bias of the Polish editors who wished to present an idealized version of the author. ${ }^{12}$ The editors omitted what would reflect poorly on Żmichowska, especially her complicated relationship with aristocratic families and the Polish independence movement.

Independent Poland in the interwar period offered an opportunity to pursue more objective, scholarly studies of Enthusiast letters. The first was Tadeusz Boy-Żeleński's Listy Narcyzy Żmichowskiej do brata Erazma (Letters from Narcyza Żmichowska to her brother Erazm), published in 1930 in the journal Pamiętnik warszawski (The Warso- 
vian journal). This series included uncensored letters sent from Żmichowska to her brother, Erazm, during her challenging time in Paris residing with and working for the powerful Zamoyski aristocratic family. The same year, Boy-Żeleński published Żmichowska's letters to his mother, Wanda Grabowska, which proved sensational because of the bond between the women. A third collection appeared in 1934: letters from 1840 to 1846 between Żmichowska and an Enthusiast who helped deliver letters to her exiled brother in Paris.

The most comprehensive collection of Żmichowska's letters are the three volumes published by Mieczysława Romankówna in 1957-1960. Romankówna planned to publish a five-volume collection with 1,185 letters. For reasons still not entirely clear, the project stalled for some five decades; only in 2007-2009 did volumes four and five finally appear. ${ }^{13}$ While these five volumes include a vast amount of materials from different archives, they are far from complete, as they encompass mostly letters from Żmichowska but lack the responses. Correspondence between the Enthusiasts remain to be discovered in various family archives, and in the archives of other prominent Polish writers and political actors of the time. ${ }^{14}$

\section{The Narcyssa and Wanda Collection}

The collection published by Boy-Żeleński in the 1930s between his mother and Żmichowska is fascinating for both the depth and breadth of the letters' content, and the way Boy-Żeleński framed the relationship between the two women. The letters appeared in print almost sixty years after the death of Żmichowska and twenty-six years following the death of Grabowska. Tadeusz Boy-Żeleński was a well-known feuilleton writer, medical doctor, and cultural critic who pushed the boundaries of Polish popular debate continuously leftward, and in doing so, won many enemies on the Catholic right and, later, among Józef Piłsudski's supporters. ${ }^{15}$ Boy-Żeleński published Żmichowska's letters during a period when he attempted to desacralize and humanize Poland's most revered writers, including Adam Mickiewicz, Stanisław Przybyszewski, and Stanisław Wyspiański. ${ }^{16}$ This project received much criticism from the Catholic right, who saw it as an attack on the Polish nation and morality itself. Some literary critics also thought that the campaign to focus on authors' personal lives, in order to make them more relatable to the public by revealing their human flaws, missed the point: the merit of the authors' works. ${ }^{17}$ Regardless, it sparked a debate in the Polish public that had never occurred with such force, and created a renewed interest in the authors and their works.

The Żmichowska project was undertaken for more personal reasons than BoyŻeleński's other pursuits, with the goal of restoring Żmichowska to what he saw as her rightful place in Poland's literary history, since she had been largely neglected since the end of the nineteenth century. Boy-Żeleński grew up with intimate knowledge of Żmichowska, since she was a very close friend of his mother's and revered in the Żeleński household (his father, Władysław Żeleński, a well-regarded professor of music in Kraków, even composed songs set to Żmichowska's poetry). But Boy-Zeleński was repulsed by his mother's cult-like fascination with Żmichowska growing up - he 
found Żmichowska's words too idealistic, her written works too "light" in comparison with richer literary works such as Shakespeare. ${ }^{18} \mathrm{He}$ was disappointed in what he thought was lacking in Żmichowska's works and too much of a self-proclaimed cynic to attempt to understand her any further. ${ }^{19}$ This greatly hurt his mother, who had moved from Warsaw to Kraków after Żmichowska's death and lacked people with whom she could confide about Żmichowska's life and works. ${ }^{20}$ She even gave Boy-Żeleński's younger brothers middle names after Żmichowska, and hoped that Boy-Żeleński, the most literary-inclined of the brothers, would continue her interest in Żmichowska and her works. He resoundingly refused, until much later, after his mother had died.

In his long and rather personal introduction to the letters, Boy-Żeleński describes how he received the letters from his aged father, long after the death of his mother. He kept them on a shelf for many years, and then one day opened them to find not only Żmichowska's letters to Grabowska, but his mother's attempts at novel writing and materials pertaining to a planned biography of Żmichowska. ${ }^{21} \mathrm{He}$ describes opening and reading the letters in this way: "A sort of fluid surrounded me that was released from these letters: so much heart, so much feeling, so much sadness, that was put in these letters and that hadn't been let out in half a century." 22 He felt a large debt to his mother, and greatly regretted not listening to her speak about Żmichowska when he was younger. ${ }^{23}$ To rectify this youthful error, he published new editions of many of Żmichowska's works along with his own commentary. He even included her in his 1929 groundbreaking Ludzie żywi (Living people) study, along with the aforementioned "sacred" national writers whom he attempted to make accessible and relatable. By the time he published the letters between his mother and Żmichowska in 1930, he had already inspired new interest in Żmichowska and her works.

Boy-Żeleński curiously only included letters from Żmichowska to his mother, Wanda Grabowska, but it is evident from his long introduction that he also had letters from his mother to Żmichowska, since he quotes from them but not in their entirety. One wonders if this decision was made to protect the memory of his mother in some way, since what he chose to publish shows a very deep bond between the women, one that he wasn't entirely comfortable with, as shown in his commentary. The letters reveal a complicated love friendship, but are also filled with discussions of then current political, social, and intellectual debates. Żmichowska was a mentor to Grabowska, whom she met while teaching at a small girls' school in Warsaw in the period before the January Uprising of 1863. According to Boy-Żeleński and what can be surmised from the letters, Grabowska was in love with Żmichowska, in awe of her literary talent and her exalted position as a cultural icon within Warsaw. ${ }^{24}$ The excerpts of Grabowska's letters to Żmichowska speak of an insatiable and unrequited love for her "Beloved." 25 They contain language usually reserved for erotic-romantic relations, and a longing by Grabowska to be loved by her idol in return. ${ }^{26}$ Boy-Żeleński considers these feelings and desires "very dangerous," and explains them as a sort of infatuation that could have left Grabowska "in the shadow of her Beloved" for the rest of her life, putting a "cross on her private life and her calling as a woman." ${ }^{27}$ He clearly regards Grabowska's relationship at the time as one of immature idolatry, and one that she had to move beyond in order to become a real woman. Interestingly, Żmichowska's 
interpretation of Grabowska's love of her is not too far off from this, at least in what is available in the published collection.

Żmichowska met young Wanda Grabowska after her time spent in prison for anti-Russian political activities in 1855. She lived in Grabowska's father's house, where she helped run a small, illegal girls' school in which she taught Grabowska and her three sisters. ${ }^{28}$ The two started their correspondence following Żmichowska's departure from Warsaw during the events of 1863 and 1864, when Polish nationalist organizations attacked Russian imperial forces in a movement known as the January Uprising of 1863. At this time, Russian police uncovered weapons held in the basement of the Grabowski house and arrested Wanda's father, Jan Grabowski. Many of Żmichowska's intellectual circle were arrested or fled. ${ }^{29}$ Żmichowska managed this time to evade arrest, but her network, and her life in Warsaw, were no more. Wanda Grabowska and her sisters remained in the house and continued to keep in contact with those who stayed. Grabowska served as one of Żmichowska's main links to Warsaw following her departure from the Grabowski household.

The letters reveal, as Boy-Żeleński's introduction suggests, a loving relationship between the two women, but one that Żmichowska treated with the kind of distance a mentor has for an overzealous student. Żmichowska encouraged Grabowska's studies and writing, and even wanted to collaborate with her, but she did not treat her on equal, reciprocal terms. She found Grabowska inexperienced and troubled, filled with idealistic passions and love that needed to be grounded and tempered. In BoyŻeleński's collection of letters, Żmichowska writes that Grabowska loved like "a bird who wants to fly in the clouds, but who despises her own wings" 30 and who gets lost in the passionate "ecstasy" of love, not its reality. Żmichowska questioned Grabowska's love for her, but was also inspired that a youthful, smart woman took an interest in her and her work at a time when her literary production was low. She even wrote that Grabowska was the very reason that she continued to learn, write, and think in her twilight years. ${ }^{31}$ Żmichowska relied on Grabowska's devotion to her in her darkest periods of her life when she was exiled from her beloved Warsaw and when her health and memory were gradually deteriorating. While Żmichowska's love for Grabowska did not reciprocate the exalted, impassioned feelings of Grabowska, it certainly was strong and vital to Żmichowska in her later years.

The letters in Boy-Żeleński's collection reveal Żmichowska's thoughts, principles, beliefs, and desires in the waning days of her life. These are not merely diary entries, depicting daily routines or personal longings and failures, although those elements are also included. Żmichowska was a literary and political figure, well-read and established in European intellectual debates. Her letters reveal the attitudes and behaviors of a generation of thinkers, writers, and political actors who had attempted to put into practice their dreams of national unity and brotherly-sisterly solidarity, only to find barriers across social, political, and gendered lines. By the time Żmichowska wrote these letters, she had seen many of her comrades sent away to exile, to jail, or to an early death. She herself was in exile from her beloved Warsaw, trying to write even though she found little impetus in the dark social and political situation. Her friends and devoted students, such as Grabowska, formed a community of women whose very existence proved that it was possible to build and sustain such a space. The let- 
ters are labors to keep these bonds alive, to keep the space functioning amid a lack of adequate support and resources to expand the group, its values, and its functions in larger society.

Currently, only snippets of correspondence between Enthusiasts' members have appeared in English. The following is the first complete translation of a letter between Żmichowska and Grabowska, taken from chapter 17 of 185 in Boy-Żeleński's collection (some of the chapters have multiple letters bundled together). It is the second of two letters from a bundle sent to Grabowska in January 1864. I have inserted paragraph breaks into the letter since it aids the reader in following Żmichowska's sometimes convoluted stream of ideas and words. I have for the most part retained her punctuation and word flow. All footnotes are my own, except those marked as original footnotes by Tadeusz Boy-Żeleński.

\section{January 1864}

Now I will put my personal affairs aside and directly confront the second part of your evening dreams. You dreamt up that some sort of educational course, or some lessons of salvation, could have a great effect on the improvement of the status of women in our country. I am completely convinced of the opposite. Every project that is tied to achieving this goal and appears under its name falls apart because of its laughable nature, or in the best of cases, its ineffectiveness. Within circles of good friends, amongst affectionate female friends we are free to deeply discuss our doubts, and even sigh with longing over this or that change, yet to the public I would never suggest to discuss things in this manner. This was not always my position, but this is what it became over the course of my life and experiences; later life and experience taught and told me a very logical theory. A woman before all else needs to "realize" herself; if the phrase wasn't overused in a very bad sense, I would say that a woman is a "realist." In her nature she is compelled to realize even the most abstract of ideals. Any premature or above all "now" fashionable ideas are the most dangerous when they end up among women, but also they are the most realizable when purpose, trial, body, and blood can make them real; a woman then, as such a serious realizer, should only work with and from reality. This must be her God's law, when all "causes," all arguments have always brought her more harm than good.

There was a time, when with much regret I thought to myself, why did Christ in his Gospels never give women a decisive blessing of equality of spirit? Now none of this offends me; I see that he gave her a lesson. Christ entrusted the Samaritan woman at the well with the most beautiful, fundamental words of his teaching; and he did not belittle this gift when he said:- "This is why I am telling you this, because you are a woman" - or "even though you are a woman" - really he was speaking to the human spirit. I also think that we are obliged not for ourselves, not for us women but for everyone, for the holy truth, to demand the truth. What use are the tracts of logic that show that women can, and therefore when they can they should, educate themselves? Begin with a shorter inquiry of education without argumentation. Does a system of educational courses prove to be inadequate? - persuade those, who have influence to change things; speak in the name of education, not in the name of our 
needs. For the rest, I am convinced that within society there is a place for every one of us according to our talents; I don't care to even demand anything more. For us it is neither any worse nor any better than the other half of the world from the viewpoint of individual self-development. If you weigh this statistically, you will be convinced that today genius and talent in both genders face the same obstacles. Prejudice does not stop it [genius and talent], it is mainly poverty and lack of a title that stand in its way.

When it comes to family relationships, this you will not solve through women; and actually one should be afraid that a certain majority of women do not form themselves to be overly perfect emotionally; you must start by thinking of men. If you within yourself were to develop all of your power for ideal family love, however much that would count for, when you are ready to fall in love with men you won't have anyone to fall in love with! Many, very many women bring with them a greater inclination toward the good, nobler nature of love. To fulfill oneself before God, to succeed in the work of eternal redemption, it is necessary for women to have the help of brotherly, male souls; it is necessary for them to have complete respect for the man whom they choose; reciprocity is essential (without reciprocity only a lower standard will result); meanwhile, as one looks around, it is firstly very difficult to find a subject that is worthy of respect-respect for a woman means complete adoration-adoration in this case is very hard - even harder, when the adored woman demands the same fundamental aspects, when she wants to go with him and take her own fulfillment that much higher - when she needs to tell him about the depths of her soul, her doubts, hopes, weaknesses, challenges. There do not exist two such brothers under the sunand as for husbands, not even one. You have probably read Mlle de La Quintinie. ${ }^{32}$ All of these anti-confessional declamations only amuse me. When there will be different brothers and husbands, then women will have no need for directors of conscience. It would be worse for humankind, if women's unique form of individuality was to be extinguished; this form must, together with a man's soul, contemplate, get to know and love God. You should start by the reform of these men, Wanda.

You reminded me that you met with Mrs. Matylda ${ }^{33}$ at Julia's. ${ }^{34}$ Are you curious about her? - according to how much I got to know her, she is the best example of the outline of ideas talked about here. In a most reliable fashion, she has brought with her into this world a very beautiful and lovely talent - she could be able to love "purely" but she is only loved sinfully. Today it is all about one's own strength; - with the lively affinity, that she actually has for me, I can surmise at how incomparably further, and more freely she could go, if her gift would be to prop herself up on the arms, on the thoughts of a beloved one. You will understand me fuller, if you consider yourself in this case. Modesty aside, my Wanda, but do you not feel within yourself the capability of the most holy, most ideal love? Perhaps you will fall in love, but I can vouch this point for you, that half of your soul's strength will not be able to find a place in which to develop any purpose or any subject. So why then add fuel to your fire, why rush toward the heavens? I would much prefer to meet him, who will be yours, and before my own death in my testament ascribe him all the powers that I did not make use of while alive. Don't suspect me only of some sort of corrupt blindness. I let you educate 
yourself, learn, read the writings of Maci $\ldots{ }^{35}$ and Buckle's ${ }^{36}$ history-but in proportion to future family affections, I find, that you have within yourself more reserves than you could possibly use. Also do not be surprised of any legend "about the good mind of Wanda": even though it is with humiliation you see in her a lack of arithmetical fluency, many grammatical shortcomings, a dearth of surnames and chronological dates, this should convince you that a good mind is not chronology, grammar, none of these things that individually exist, but something else. I have known unintelligent grammarians, and also stupid arithmeticians; I'm sure you know of at least one? We'll further discuss this hypothesis. Now I will tell you, my dear, that I absolutely cannot fathom, why the government does not wish for Julia ${ }^{37}$ to be married during this Carnival season? One must of course expect that the government won't forever lay down its veto [to the marriage], but also in special circumstances, people must move on. I very much understand, that you all want to give Julia your support and efforts until the last moment, but if I were there, having for the first time and for the rest of my days to live under an obligation, I wouldn't be able to stand all this wavering-and I would just as well start on the path myself-ha! these are not normal times. On the other side, I would not propose my path to anyone-they must emerge from their own initiative. What does it mean, Wanda, that after you mentioned Seweryn ${ }^{38}-$ you wrote $M r$. Lud$w i k^{39}$ - and nothing else? Is he also on his way? Or still learning? I have to at least once in my life write to Mr. Henryk, ${ }^{40}$ it's only through you from whom I expect a message from Mrs. Bolesława about her permanent address, and through you I send Mrs. Bolesława $^{41}$ my grateful and friendliest greetings. That, what you told me about the Gerson $^{42}$ painting, proves unhappily my own reflections. His earlier works, perhaps considered lower in terms of artistic quality, unequally depicted more [Polish] national topics, and slowly, from a certain point, German motifs began taking over. His Madonna, sitting on a cloud like one sits on a chest, already has too much of an Elbian tone. ${ }^{43}$ It might be strange to think about how this influence came about in the current moment; it's completely logical though that these two things are linked. Today, the whole of one's nature must be soaked in not only love and human will, but also in the grounded juice of such a nationalism that can hold unhappiness, mistakes, it moves beyond its own desires and hardships - and younger souls fall faint-God forbid they get stones thrown at them for that.

Until the next letter, I bid you good-bye, Wanda; give everyone there my embraces and greetings - to each person as they are due. And from me, for every person you tell me about, another mark will go into the treasure of debts that I owe you.

$N B$-Considering the large amount of sections and verses, two separate passages of the Holy Bible are missing. I'm surprised that you didn't get them at first-Acts of the Apostles, ch. 12-v. 8. "And the angel said to him: 'Put on your clothes and sandals.' And he did that. And the angel said to him, 'Put on your coat and follow me.'"

If it weren't for the rush to get to the post office, maybe I wouldn't send you this letter. I absolutely had other intentions, but I had to take it apart and put it back together again in a completely different way. I'll be happy when maybe I'll have more free time, and then I'll respond better.

All of these unfinished pieces I complete with kisses for your forehead and eyes. 


\section{$\diamond$ About the Translator}

Natalie Cornett is a PhD candidate at Brandeis University. She works on women's and gender history, and the provisional title of her dissertation is: "The Politics of Love: The 'Enthusiasts' and Feminism in Nineteenth-Century Poland." She has presented and published on topics concerning feminism, Jewish-Polish relations, and right-wing political movements both in the United States and Europe. Her research and teaching interests include nationalism, social power dynamics, and the history of women and sexuality. In addition to writing her dissertation, Natalie is coediting an anthology on feminist transgressions in Polish history. Email: ncornett@brandeis.edu

\section{$\diamond$ Notes}

1. Mieczysława Romankówna, "Sprawa Entuzjastek" [The case of the Enthusiasts], Pamiętnik literacki: Czasopismo kwartalne poświęcone historii i krytyce literatury polskiej [Literary memoir: Quarterly magazine devoted to the history and criticism of Polish literature] 48, no. 2 (1957): 516-537; Tadeusz Żeleński, Pisma: Ludzie żywi [Writings: Living people], vol. 3 (Warsaw: Państwowy instytut wydawniczy, 1956); Józef Bachórz and Alina Kowalczykowa, Słownik literatury polskiej XIX wieku [The dictionary of Polish literature of the nineteenth century], Wyd. 4 bez zmian. (Wrocław: Zakład Narodowy im. Ossolińskich-Wydawnictwo, 2009).

2. Narcyza Żmichowska, Pisma Narcyzy Żmichowskiej, (Gabryelli) z życiorysem autorki skreślonym przez Piotra Chmielowskiego [The writings of Narcyza Żmichowska, (Gabryella) with a biography of the author by Piotr Chmielowski], vol. 5 (Warsaw: Nakł. Michała Glücksberga, 1885), 568.

3. Aleksander Gella, "The Life and Death of the Old Polish Intelligentsia," Slavic Review 30, no. 1 (March 1971): 1-27; Norman Davies, God's Playground: A History of Poland, vol. 2 (Oxford: Oxford University Press, 2005), 134; Peter Brock, "Polish Nationalism," in Nationalism in Eastern Europe, ed. Peter F. Sugar and Ivo J. Lederer (Seattle: University of Washington Press, 1969), 313-314.

4. Gella, “The Life and Death,” 1, 15.

5. Romankówna, "Sprawa Entuzjastek," 517; Grażyna Borkowska and Ursula Phillips, Alienated Women: A Study on Polish Women's Fiction, 1845-1918 (Budapest: Central European University Press, 2001): 3-6.

6. Mirella Kurkowska, “Narcyza Żmichowska w środowisku warszawskim lat czterdziestych XIX w." [Narcyza Żmichowska in the Warsaw environment of the 1840s], in Kobieta i świat polityki: Polska na tle porównawczym w XIX i w początkach XX wieku [Women and the political world: Poland against a comparative background in the nineteenth and early twentieth centuries], ed. Anna Żarnowska and Andrzej Szwarc (Warsaw: Wydawn. DiG : Instytut Historyczny Uniwersytetu Warszawskiego, 1994), 243.

7. Wiktoria Śliwowska, "Kobiety w konspiracjach patriotycznych lat czterdziestych XIX wieku (Ewa Felińska, Eleonora Wolańska i inne)" [Women in patriotic conspiracies of the 1840s (Ewa Felińska, Eleonora Wolańska, and others)], in Żarnowska and Szwarc, Kobieta i świat polityki, 46-47.

8. Narcyza Żmichowska to Bibianna Moraczewska, 23 September 1846, in Listy, T. 2, Rozdroża [Letters, Vol. 2, Crossroads], ed. Mieczysława Romankówna (Wrocław: Zakład Narodowy im. Ossolińskich-Wydawnictwo, 1960), 41-42; Narcyza Żmichowska to Erazm Żmichowski, Spring of 1843, in Listy, T. 1, W kręgu najbliższych [Letters, Vol. 1, The innermost circle], ed. Mie- 
czysława Romankówna (Wrocław: Zakład Narodowy im. Ossolińskich-Wydawnictwo, 1957), 157-158.

9. Żmichowska, Pisma Narcyzy Żmichowskiej, 564-565; Narcyza Żmichowska and Julia Baranowska, Ścieżki przez życie: Wspomnienia [Pathways across life: Memories], ed. Mieczysława Romankówna (Wrocław: Zakład Narodowy im. Ossolińskich-Wydawnictwo, 1961), 223.

10. Archiwum Główne Akt Dawnych w Warszawie [The central archives of historical records in Warsaw] Zespół nr 241, sygn. 1. Postojannaja Wojenno-Sledstwiennaja Komissija T.1. (Stała Komisja Wojenno -Śledcza-spisy osobowe T.1.) [Permanent military-investigative commission V.1 (Permanent military-investigative commission-inventories of persons V. 1)], 18331862. I/3039-42.

11. Ibid.

12. Barbara Zwolińska, O kwestiach kobiecych w korespondencji Narcyzy Żmichowskiej [Women's issues in the correspondence of Narcyza Żmichowska] (Gdańsk: Wydawn. Uniwersytetu Gdańskiego, 2007), 15-18.

13. Barbara Zwolińska mentions that volume 4 was meant to be the largest of the collection and required particular attention because of mistakes in previous editions and poor chirography. This might be why Romankówna never finished editing them. See Zwolińska, O kwestiach kobiecych, 24-25; Narcyza Żmichowska, Listy, Tom IV, Rozmowy z Julia [Letters, Vol. IV, Conversations with Julia], ed. Barbara Winklowa (Fundacja Akademia Humanistyczna and IBL PAN, 2009), 799.

14. Zwolińska, O kwestiach kobiecych, 23.

15. For more of a political context of Boy-Żeleński's actions, consult Eva Plach, The Clash of Moral Nations: Cultural Politics in Piłsudski's Poland, 1926-1935 (Athens: Ohio University Press, 2014), esp. chap. 5.

16. Barbara Winklowa, Nad Wista i Nad Sekwana: Biografa Tadeusza Boya-Żeleńskiego [On the Vistula and the Seine: A biography of Tadeusz Boy-Żeleński] (Warsaw: Wyd. Iskry, 1998), 136.

17. Ibid.

18. Tadeusz Boy-Żeleński, ed., Narcyssa i Wanda: Listy Narcyzy Żmichowskiej do Wandy Grabowskiej (Żeleńskiej) [Narcyssa and Wanda: Letters from Narcyza Żmichowska to Wanda Grabowska (Żeleńska)] (Warsaw: Dom Książki Polskiej Spółka Akcyjna, 1930), vi-x.

19. Ibid.

20. Ibid., v-vi.

21. Ibid., ix.

22. Ibid.

23. Ibid.

24. Żmichowska by the 1860s had published in many organs and journals and was well connected among intelligentsia circles both within the Polish territories and abroad. See Mieczysława Romankówna, Narcyza Żmichowska (Gabriella), Polska Akademia Nauk Oddział w Krakowie, Nauka Dla Wszystkich [Polish Academy of Sciences Kraków Section, Education for All], nr 118 (Kraków: Państwowe Wydawnictwo Naukowe, 1970), 651, for a list of her literary accomplishments and social connections.

25. Boy-Zeleński, Narcyssa, xxii-xxiii.

26. Ibid.

27. Ibid, xxiv.

28. Ibid., xiii.

29. Ibid., xiv-xv.

30. Ibid., 108.

31. Ibid., 173. 
32. Novel by George Sand (1863) that was a response to Histoire de Sibylle [Sibylle's story] by Octave Feuillet. Sand presents a free, educated woman to counter Feuillet's sensitive, religious female character. (Original note by Tadeusz Boy-Żeleński.)

33. Matylda Natansonowa, cousin of Henryk Wohl, a member of the 1863 January Uprising. Żmichowska first met Natansonowa in 1862 when she visited a Jewish school where Natansonowa was a tutor. Żmichowska wanted to start a women's school together with Natansonowa, Julia Baranowska, and Izabela Zbiegniewska.

34. Julia Bąkowska (later Baranowska) ran the private women's school where Narcyza Żmichowska taught Wanda Grabowska.

35. Wacław Maciejowski, Piśmiennictwo polskie od najdawniejszych czasów aż do r. 1830 [Polish literary works from the oldest times until 1830] (Warsaw: S. Orgelbrand, 1851). (Original note by Tadeusz Boy-Żeleński.)

36. English historian Henry Thomas Buckle, author of History of Civilization in England, published in 1857.

37. Julia Grabowska, the older sister of Wanda Grabowska who eventually married Adolf Tetmajer. Adolf Tetmajer was a nobleman who fought in the November 1830-1831 uprising and was a lifelong supporter of the Polish cause. His political orientation and background might have been the reason for officials delaying the marriage.

38. Seweryn Markiewicz was a close friend of Żmichowska who lived in the Grabowski household with his mother, sister, and brother. He was also part of the Millenerze (Thousands) intellectual circle, linked with Edward Jurgens and the White Camp of the 1863 January Uprising. He was arrested in 1863 and exiled to Jadrin in the Kazan Governorate for his participation in the uprising.

39. Ludwik Lewiński, Żmichowska's nephew who was arrested in connection with his participation in the 1863 January Uprising. He was held in the Warsaw Citadel and sent to Siberia. Żmichowska here seems to be asking if, as Markiewicz, he is on his way to an internment camp, or still "learning," an allusion to being held in the Warsaw Citadel under interrogation by Russian authorities.

40. Henryk Wohl, cousin of Matylda Natansonowa. Wohl was an 1863 January Uprising insurrectionist and director of the Treasury Department of the underground Polish National Government. Since 1859, he was part of Jurgens's Millenerze group and was sent to exile in Siberia as punishment for his crimes. Żmichowska sometimes corresponded with him through Wanda Grabowska and Seweryn Markiewicz.

41. Bolesława Rodysowa, cousin of Henryk Wohl, and friend of Żmichowska, Matylda Natansonowa, and the Grabowski family.

42. Wojciech Gerson (1831-1901) was a famous realist Polish painter based in Warsaw of French and German roots. Żmichowska here doubts his national heritage and artistic devotion to Polish themes.

43. Elbian here refers to the Elbe River and the surrounding region; it is another reference to Gerson's German heritage as evident in the style of his painting. 